\title{
Knowledge spillovers, entrepreneurship and economic development
}

\author{
Roger Stough • Peter Nijkamp
}

Published online: 31 March 2009

(C) The Author(s) 2009. This article is published with open access at Springerlink.com

Knowledge spillover refers to the diffusion or sharing of knowledge from where it is created or from one to another agent in society. It is in this way that it becomes useful beyond the sequestered knowledge of an individual agent and thus acquires societal value. There are many factors that constrain or hinder the flow of knowledge and the sum total of these factors is referred to by some as the "knowledge filter" (Acs et al. 2004; Audretsch et al. 2006). To be more explicit, when the corpus of factors that constrain the flow of knowledge is great or strong the knowledge filter bottlenecks the flow and vice versa when the constraining factors are weak. Fundamental among the various technical and institutional factors that make up the "knowledge filter" is proximity. It is argued that knowledge tends to spill over more easily when the source of the knowledge is near the agent or place where it "spills" to, ceteris paribus. There is considerable interest in the literature on the nature of the proximal effect as well as the other factors impacting the flow of knowledge (see for example, Agrawal et al. 2003; Fischer et al. 2001; Karlsson and Manduchi 2001; Jaffe et al. 1993; Koo 2007; Autant-Bernard et al. 2007).

The impetus of this mini-special edition on knowledge spillover stems from the continuing quest to better understand the role of proximity and other factors that impact the rate at which knowledge flows through the filter. The associated papers are all empirical in nature and thus help to extend the factual based understanding of knowledge spillovers.

\footnotetext{
R. Stough

George Mason University, Fairfax, VA, USA

e-mail: rstough@gmu.edu

P. Nijkamp ( $\varangle)$

VU University Amsterdam, Amsterdam, The Netherlands

e-mail: pnijkamp@feweb.vu.nl
} 
Why should society be interested in the knowledge spillovers generally and the proximity effect more specifically? To answer this question it is helpful to review the concept of regional innovation systems (RIS). There are many definitions of regional innovation systems and in keeping with these one may define a regional innovation system (RIS) as the hard (physical) and soft (institutional) infrastructure that enables a region to detect effects of external as well as endogenous change and to mobilize and structure/restructure itself in ways that effectively promote its sustained growth and development, including by production and use of scientific and technical knowledge to adjust well to changing conditions such as those induced by cyclical factors, new generic technology, natural and man made disasters, and changing industrial structures (e.g., de-industrialization). While this definition is our creation, it is not inconsistent with that by Carlsson et al. (2002) or others that appear in the literature (e.g., Katz 2006). From this it is easy to see the significant role that knowledge plays in the innovation process, generally and at the regional level, in that without knowledge production on the one hand and its spillover into the innovation and economic growth/development process economic growth and development would be considerably limited. Given that proximity is recognized by a wide range of scholars as an important element of the knowledge filter empirical research about its effects and ways in which it may or may not interact with other factors and processes such as human capital, entrepreneurship, migration, whether the knowledge is codified or tacit, and so on offers the possibility of greater understanding of factors that impact the process and thus the ways in which public policy may be used to guide the evolution of more productive regional innovation systems.

This mini special collection of papers is presented in the tradition of the knowledge spillover literature and yet, at the same time, provides further insight into the role of proximity. The first paper is by Manfred Fischer, Thomas Scherngell and Eva Jansenberger and is entitled "Geographic Localization of Knowledge Spillovers: Evidence from High-Tech Patent Citations in Europe”. The paper finds a strong relationship between the locations of patents relative to earlier related patents and thus that localization of knowledge spillover exists. However, the paper finds that there is an even stronger and therefore more important border effect, i.e., national borders are strong elements of the "knowledge filter" among European countries. In short, geography matters at the macro level and in terms of technological proximity or at the micro/local level. The paper also finds that the strength of these findings varies by industry sector.

A second paper by Frank van Oort, Johan Oud and Otto Raspe entitled "The Urban Knowledge Economy and Employment Growth: A Spatial Structural Equation Modeling Approach". The structural equation approach adopted in this paper enables the investigators to examine the effect of latent knowledge economy factors by linking them in the analysis to their observable indicators. Thus in addition to more conventional determinants of employment growth the investigation is able to explore the effects of spatial spillovers, degree of urbanization and core-periphery dichotomy effects. Density of knowledge workers (knowledge production and potential spillover effects) and innovativeness (evidence of knowledge spillovers) were found to have strong and positive impacts. The investigators argue that these effects are stronger in larger urban places due to the larger agglomeration effects known to exist there. 
The third paper by Marina van Geenhuizen and Peter Nijkamp entitled "PlaceBound Versus Footloose firms: Wiring Metropolitan Areas in a Policy Context" examines the rise of the multi-nodal city or more generally the demise of the core dominated city. In the past coordination functions, high end services and innovation were concentrated in the geographic cores of metropolitan regions. Today the spatial arrangement of these functions are more distributed or diffused across larger metropolitan spaces. The paper among other things considers policies dealing with information and communication technology and consequently knowledge spillover processes are seen to evolve from related urban dynamics. Given that young innovative firms are core agents of knowledge spillovers and that these are often more footloose than others, they are seen as drivers of economic renewal as well as knowledge spreading agents of the process. The authors use a methodology called rough set analysis to examine results of semi-structured interviews of a sample of young innovative firm managers to examine the envisioned role of these agents as knowledge transfer agents in a changing urban/metropolitan landscape.

The fourth and final paper is by David Audretsch and Taylor Aldridge and is entitled "Scientist Commercialization as conduit of knowledge Spillovers". This paper is consistent with the frame offered earlier in this paper on regional innovation systems and the centrally important role knowledge spillovers provide in the maintenance and operation of such systems and at the same time to economic growth and development. The empirical part of the paper is an examination of the propensity of scientists to be both the creators of knowledge on the one hand and the agent examines the ability of scientists to "combine scientific creativity with entrepreneurial creativity". The research finds that the human capital (amount of knowledge possessed) and reputation of the scientist on the one hand and regional milieu and type of institution where the scientist is located on the other, are the most important factors in the success of scientist as entrepreneur and thus as agents of scientific knowledge spillover leading to new economically productive knowledge.

Open Access This article is distributed under the terms of the Creative Commons Attribution Noncommercial License which permits any noncommercial use, distribution, and reproduction in any medium, provided the original author(s) and source are credited.

\section{References}

Acs Z, Audretsch D, Braunerhjelm P, Carlsson B (2004) The missing link: the knowledge filter and entrepreneurship in endogenous growth. Center for Economic Policy Research (CEPR), Discussion Paper.

Agrawal A, Cockburn M, McHale J (2003) Gone but not forgotten: labor flows, knowledge spillovers and enduring social capital. NBER Working Paper 9950, Cambridge, MA

Audretsch DB, Keilbach MC, Lehmann EE (2006) Entrepreneurship and economic growth. Oxford University Press, Oxford

Autant-Bernard JM, Massard N (2007) Spatial Knowledge diffusion through collaborative networks. Pap Reg Sci (special issue)

Carlsson B, Staffin J, Magnus H, Rickne A (2002) Innovation systems: analytical and methodological issues. Res Policy 31:233-245. doi:10.1016/S0048-7333(01)00138-X

Fischer M (2001) Innovation, knowledge creation and systems of innovation. Ann Reg Sci 35:199-216. doi: $10.1007 / \mathrm{s} 001680000034$

Jaffe AB, Trajtenberg M, Henderson R (1993) Geographic localization of knowledge spillovers as evidenced by patent citations. Q J Econ 108:577-598 
Karlsson C, Manduchi A (2001) Knowledge spillovers in a spatial context-a critical review and assessment. In: Fischer M, Frohlich J (eds) Knowledge, complexity and innovation systems. Springer, Heidelberg pp 101-123

Katz JS (2006) Indicators for complex innovation systems. Res Policy 35:893-909. doi:10.1016/j.respol. 2006.03.007

Koo J (2007) Determinants of localized technology spillovers: Role of regional and industrial attributes. Reg Stud 41(7):995-1011. doi:10.1080/00343400601142746 